\title{
Convergence or Divergence of National Legal and Administrative Structures? Europeanisation Effects of the Environmental Impact Assessment in Germany and England (Part 2)*
}

\author{
Christoph Knill and Daniela Winkler**
}

\section{Implementation in both countries}

\section{Legal implementation}

\section{a. Germany}

\section{Formal transformation}

Up to now, the transformation of European law specifications into national law has taken place in various steps on the basis of the Environmental Impact Assessment Act (Gesetz zur Umweltverträglichkeitsprüfung) from $2 / 12 / 1990,78$ the Amendment Act (Artikelgesetz) from $7 / 27 / 2001^{79}$ as well as the European Law Adaptation Act for the Construction (Europarechtsanpassungsgesetz $\mathrm{Bau}$ ) from 6/24/2004 Furthermore, the Directive $2003 / 35 / E^{80}$ is intended to be implemented through a public participation Act $^{81}$ as well as a right of appeal Act for the environment. ${ }^{82}$

Since 1992, a comprehensive restructuring and aggregation of the diverse environmental laws into one systematic code (a so-called General Environ-

* Part 1 was published in JEEPL 1/2006, pp. 43-51.

** Prof. Dr. Christoph Knill is Professor of Political and Administrative Science at the University of Konstanz, Department of Politics and Management, and Dr. Daniela Winkler is Research Associate at the University of Tübingen, Law Department.

78 Bundesgesetzblatt I 1990, 205.

79 Act on implementing the EIA amendment directive, the IPPCDirective and further directives on environmental protection (Bundesgesetzblatt I, 1950); see Koch/Siebel-Huffmann, Neue Zeitschrift für Verwaltungsrecht 2001, $1081 \mathrm{ff}$.

80 See the exact verification in footnote 9.

81 Gesetz über die Öffentlichkeitsbeteiligung in Umweltangelegenheiten nach der EG-Richtlinie / Act on Further Development of Public Participation in Environmental Matters according to the EC Directive 2003/35/EC.

82 Gesetz über ergänzende Vorschriften zu Rechtsbehelfen in Umweltangelegenheiten nach der EG-Richtlinie / Act on Supplementary Provisions on Legal Appeals in Environmental Matters according to the EC Directive 2003/35/EC.

83 According to the statement of the Federal Environmental Ministry on the Internet, http://www.bmu.de/sachthemen/gesetz/ mental Act or Umweltgesetzbuch) has been envisaged as an alternative to the piece-by-piece 'postprocessing' of German environmental law. However, this has been impeded by the highly differentiated allocation of legislative powers. ${ }^{83}$ The solution to the above-mentioned problems proposed by the planned Environmental Act was supposed to be the introduction of a concentrated and thus a crossmedia project authorisation $\left(\mathbb{\int} \int 80\right.$ I 1,99 I 1, 2 Umweltgesetzbuch-Kommissionsentwurf), ${ }^{84}$ which would have simplified the administrative structure to one authorizing authority. ${ }^{85}$ At the same time, the English concept of the Best Practicable Environmental Option (BPEO) was referred to. ${ }^{86}$ Instead however, the EIA Directive was implemented by introducing a Basic EIA Act (Umweltverträglichkeitsprüfungsgesetz [UVPG]) and supplementary amendments to specific relevant legal regulations (e.g. in the Federal Immission Control Act and the Atomic Energy Act). The EIA is accordingly conceived as an institution that is dependent on

umweltgesetz.php (consulted on 5/20/05). According to another view, sufficient expertise can be created by combining skills; see Breuer, Gutachten B für den 59. DJT (Expert Opinion for the German Jurists Conference), p. B 1 (B 21 f.); Böhm, Zeitschrift für Umweltrecht 2002, 6 (6 f. in particular footnote 4); Kloepfer/Kunig/Rehbinder/Schmidt-Aßmann, Deutsches Verwaltungsblatt 1991, 339, 340. See also Volkmann, Verwaltungsarchiv 89 (1998), 363, 368: ,(Das Integrationsprinzip) verbindet sich damit beinahe von selbst mit der angestrebten Schaffung eines Umweltgesetzbuches.'

84 See Bundesumweltministerium (Ed.), Umweltgesetzbuch-KomE, Einleitung, p. 76; before $\S \S 80-114,615$. $\S 8$ Umweltgesetzbuch-KomE also stresses the protection of the environment in its entirety and thus the integrative approach of the German Environmental Code (Umweltgesetzbuch). However, the conditional structure of norms would have remained unchanged according to this; critique of this in Breuer, Archiv des öffentlichen Rechts 127 (2002), 523, $563 \mathrm{f}$.

85 Bundesumweltministerium (ed.), Umweltgesetzbuch-KomE, $\S \S 83-100,656$.

86 Bundesumweltministerium (ed.), Umweltgesetzbuch-KomE, $\S \S 80-114,622$; see Ladeur, Zeitschrift für Umweltrecht 1998 245, 249; Zöttl, Journal of Environmental Law 2000, 281, 281. 
existing authorisation procedures through administrative agencies $(\mathbb{} 2(1)$ sent. 1 of the German EIA Act), the structure of which remains unchanged even when the German EIA Act (UVPG) applies. Such a decision can also be designed as an authorisation $(\mathbb{2} 2(3)$ No. 3 of the German EIA Act).

\section{Substantive structure}

Procedural component

The procedural component of the EIA places its focus on executing the EIA. Compliance with the required participation of the public as well as the coordination of various linked authorisation procedures, where applicable, must be considered in this context. According to the specifications of the German EIA Act and various specific laws (Federal Building Code - BauGB; Ordinance on Atomic Energy Procedures - AtVfV), the material for investigation gathered (also) with the participation of the citizens is to be assessed and compiled in an environmental report, which - besides a description of the environmental influences that come into consideration - also partly illustrates possible alterna-

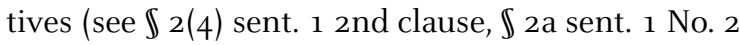
Baugesetzbuch / German Building Code in conjunction with Appendix. No. 2.d). In accordance with

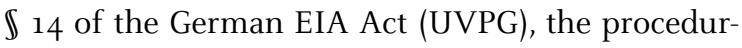
al integration takes place by specifying a leading agency that is in charge of basic duties such as determining the object to be examined as well as the summarised illustration of the environmental impact. Its function is not only restricted to that of a moderator, rather it is authorised to put forward suggestions in view of the overall evaluation. ${ }^{87}$

The relatively insignificant procedural aspect in German law is expressed in particular by the limit-

87 Barth/Demmke/Ludwig, Natur und Recht 2001, 133, 135.

88 From now on in the version of the Adaptation Act to EU law for Construction (EAG Bau). On the previous legal situation after the Act on the implementation of the EIA Modification Directive see Gaentzsch, Umwelt- und Planungsrecht 2001, 287, 292; Stollmann, Natur und Recht 2003, 586, 591.

89 The restriction previously made by $\S 214(1)$ sent. 1 No. 1 2nd clause in conjunction with $\S 3(2)$ sent. 2 of the Baugesetzbuch (old version) has become superfluous by the extension of the EIA to all construction plans.

90 Stollmann, Natur und Recht 2003, 586, 591.

91 See e.g. Entscheidungssammlung des Bundesverwaltungsgerichts 100, 238, $251 \mathrm{ff}$; 98, 339, $361 \mathrm{f} . ;$ on the status of the jurisdiction, see also Ladeur/Prelle, Journal of Environmental Law 2001, 186, 186 ff.; for a critique see Schmidt-Aßmann, supra note 43 , Chapter 6 , sidenote 113 . ed attention given to procedural errors. This is exemplified, first of all, by the specifications of the land use planning (Bauleitplanung), which standardises rules on what is called plan maintenance (Planerhaltung) in $\iint 214 \mathrm{f}$. of the Building Code (Baugesetzbuch). ${ }^{88} \mathbb{\int} 214(1)$ of the Building Code explicitly mentions those procedural errors which result in the inoperativeness of the plan. As for the EIA procedure, this applies to errors in drawing up the environmental report. Moreover, the specifications on the consideration of the lack of public par-

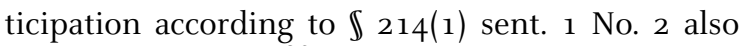
gain in importance. ${ }^{89}$ Substantial procedural errors in this regard can be remedied by the expiry of the time limit according to $\mathbb{2 1 5}(1)$ No. 1 of the Building Code. When the environmentally relevant aspects have been processed correctly and the error essentially has to do with the fact only that a formal summary of this process in compliance with the specifications of the EIA is missing, it is possible to rectify the error in the supplementary procedure

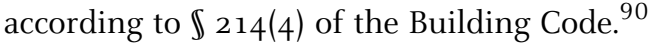

The implementation of the EIA by means of the plan approval and authorisation procedure is even more restrictive and is not attributed any significance of its own, meaning that, according to the jurisdiction of the Federal Administrative Court (Bundesverwaltungsgericht), non-compliance alone cannot lead to the abrogation of a decision. ${ }^{91}$ Since the law accordingly does not grant the EIA any enforceable legal position of its own, but rather only serves to enhance the implementation of environmental concerns, the citizen affected by a decision can thus, up to now, only restrictedly request the legal support of a court on the basis of the lack of the EIA. With reference to $₫ 46$ of the German Administrative Procedure Act (Verwaltungsverfahrensgesetz), this legal decision only leads to the revocation of the decision for authorisation, when, depending on the circumstances of the case, there is the concrete possibility that a different decision would have been made without the assumed procedural error. This also applies when the legally required EIA is neglected. However, this legal decision stands in contrast to Article 10a of the EIA Directive introduced through Directive 2003/35/EC, according to which the verification of the substantive, legal and procedural lawfulness of a decision for the authorisation of a project subject to the EIA can be filed for. To implement this regulation, $\mathbb{3} 3$ of the draft of the environmental right of appeal Act 
(Umwelt-Rechtsbehelfsgesetz) develops its own means of dealing with errors which deviates from $\mathbb{\int} 46$ of the Administrational Procedure Act (Verwaltungsverfahrensgesetz). This serves to legally establish whether certain severe procedural errors during future authorisation decisions can lead to their revocation if the respective procedural steps are not made up for $\left(\mathbb{\int} 45(2)\right.$ of the Verwaltungsverfahrensgesetz) and the procedural errors are thereby remedied. Examples of severe procedural errors are the total failure to carry out a legally stipulated EIA or preliminary examination of the EIA requirements of the individual case as well as the failure to carry out a single legally stipulated procedural step of the EIA. For resolutions in terms of $\mathbb{\int} 2(3)$ No. 3 of the German EIA Act (UVPG), a deviant reference is made to $\iiint_{214} \mathrm{f}$. BauGB (Building Code) in $\mathbb{\int} 3(2)$ of the draft of the environmental right to appeal Act.

\section{Substantive component}

Furthermore, according to European Law the EIA also contains a substantive component which requires the result of a properly conducted EIA to be incorporated into the authority's decision. Strictly speaking, however, the German EIA Act only has a procedural focus. ${ }^{92}$ Signs of a substantive law approach can only be found in $\mathbb{\int 1 2}$ of the German EIA Act, which stipulates an evaluation and consideration requirement in accordance with the applicable laws' and by which the integrative capacity of the EIA results remain subject to the concrete execution of the respective decision-making procedure. $^{93}$ According to the conceptual design of German law, the EIA requirement can exist both on an initial planning level (see $\mathbb{1} 16(1)$-(3) of the German EIA Act, $\mathbb{\int} 2(4)$ of the German Building Code) and on a subsequent project-related level (see

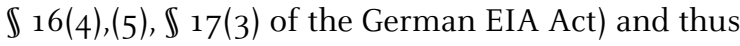
be linked to procedures with both final and conditional structures.

\section{Final procedures}

The conditionally designed plan approval and planning procedures are the practical starting point for the initiation of an environmental impact assessment. Due to their concentrating effect and the inherent aspect of weighing and assessing various options they incorporate all elements of the environment and are conditionally structured. ${ }^{94}$ Along with that, observers agree that they also provide a basis for evaluations of alternatives. ${ }^{95}$ During the plan approval procedure, the need to take environmental sustainability into account is in part explicitly standardised by means of weighing and assessing various options. ${ }^{96}$ As a concession to the European regulation, the decision between a plan approval procedure and a plan authorisation is also made dependent on the EIA requirement of the project. ${ }^{97}$ Land use planning (Bebauungsplanung) can be regarded as a particularly implementationfriendly planning procedure, as it already requires the consideration of determined environmental effects according to $\mathbb{1} 1(6)$ No. 7 of the German Building Code. ${ }^{98}$ By these means, the procedural law provisions are connected with substantial criteria through the reference to construction law and its weighing and assessing imperative as stipulateded in $\mathbb{1} 1(7)$ of the German Building Code. ${ }^{99}$ The observance of the results of the environmental report during the assessment is now required

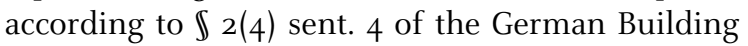
Code. The interplay between different elements of the environment, which also must be incorporated,

92 See only Stollmann, Natur und Recht 2003, 586, 588.

93 For the development of case law in conformity with European law see Nettesheim, Archiv des öffentlichen Rechts 119 (1994), 261, $282 \mathrm{ff}$.

94 General view, see only Beckmann, supra note $18, \S 12$ sidenote 81; Bunge, Handbuch der Umweltverträglichkeitsprüfung, 29th ed. (1998), § 12 UVPG (German EIA Act) sidenote 86; Erbguth/Schink, supra note 18, § 12 sidenote 33; Hoppe/Beckmann/Kauch, Umweltrecht, § 8 sidenote 93; Schmidt-Aßmann, ,The implementation of the EC-Directive on the Environmental Impact Assessment into national law', in: Hailbronner/Ress/Stein (eds.), FS Doehring, 889, 891; Steinberg, Deutsches Verwaltungsblatt 1988, 995, 998; Wahl, Deutsches Verwaltungsblatt 1988, 86, 89.

95 Erbguth, Neue Zeitschrift für Verwaltungsrecht 1992, 209, $209 \mathrm{ff}$.

96 See the back reference to substantive law in $\$ 17(1)$ sent. 2 of the Fernstraßengesetz (Highway Act); $§ 18(1)$ sent. 2 of the Allgemeines Eisenbahngesetz (General Railways Act); § 28(1) sent. 2 of the Personenbeförderungsgesetz (Passenger Transport Act); $\S 14$ (1) sent. 2 of the Wasserstraßengesetz (Waterways Act); apparently also $\S 9 \mathrm{~b}(2)$ sent. 2 in conjunction with para. 4 No. 2 of the Atomgesetz (Atomic Energy Act).

97 See e.g. § $17(1 \mathrm{a})$ No. 1 of the Fernstraßengesetz (German Highway Act); § 18(2) sent. 1 No. 1 of the General Railways Act (Allgemeines Eisenbahngesetz); § 28(1a) No. 1 of the Passenger Transport Act (Personenbeförderungsgesetz); § 31(3) of the Wasserhaushaltsgesetz (Water Management Act); § 14(1a) No. 1 of the Wasserstraßengesetz (German Waterways Act); § 31(3) sent. 1 Nos. 1, 2 of the Kreislaufwirtschafts- und Abfallgesetz (Closed Substance Cycle and Waste Management Act); § 11a(1) sent. 1, 2 of the Energy Management Act (Energiewirtschaftsgesetz).

98 See also Wulfhorst, Umwelt- und Planungsrecht 2001, 246, 252.

99 Stollmann, Natur und Recht 2003, 586, 588 f.; see also Wulfhorst, Umwelt- und Planungsrecht 2001, 246, 246 ff. 
constitutes the normative gateway for the integrative approach of the EIA. ${ }^{100}$ Linking the content of the planning decision to the EIA result is not associated with this, ${ }^{101}$ something which is not required according to the directive. In addition, the German Building Code stipulates very extensive special legal obligations for the evaluation of alternatives. ${ }^{102}$ An essential element of the assessment according to $\mathbb{\int} 1(7)$ of the Building Code is the examination of various solutions and the consideration of more proximate and better alternatives (see also $\int 3(1)$ sent. 1 of the German Building Code Baugesetzbuch).

\section{Conditional Procedures}

With respect to conditionally structured procedures, the legal circumstances appear to be more difficult. To the extent that the specific legal norms have remained unchanged even after the introduction of the EIA Act, one would have to consider whether they have undergone substantive law modifications due to the cross-media approach explicitly stipulated in $\mathbb{2} 2(1)$ sent. 2 No. 4 of the German EIA Act. ${ }^{103}$ In this case, $\mathbb{} 12$ of the EIA Act would have the function of a legal rule of interpretation for specific laws, which, in individual cases, could change the conventional understanding of specific

100 Stollmann, Natur und Recht 2003, 586, 589.

101 See only Stollmann, Natur und Recht 2003, 586, 589.

102 Wulfhorst, Umwelt- und Planungsrecht 2001, 246, 248.

103 For instance Beckmann, Die öffentliche Verwaltung 1987, 944, 952 f.; Bohne, ,Umweltrechtliche Rechts- und Verwaltungsvorschriften auf dem Prüfstand', in: Breuer/Kloepfer/Marburger/ Schröder (eds.), Jahrbuch des Umwelt- und Technikrechts 15 (1991), 21, 34; Bunge, in: Storm/Bunge (eds.), Handbuch der Umweltverträglichkeitsprüfung, 29th ed. (1998), § 12 EIA Act (UVPG) sidenote 116 ff., 120 ff.; Erbguth, Neue Zeitschrift für Verwaltungsrecht 1988, 969, 973; Erbguth/Schoeneberg, Wirtschaft und Verwaltung 1985, 102, 117 f.; Feldmann, Umweltund Planungsrecht 1991, 127, 130 f.; Lange, Die öffentliche Verwaltung 1992, 780, 781, 785 f.; Peters, Umwelt- und Planungsrecht 1994, 281, 283; Lange, Umwelt- und Planungsrecht 1995, 300, 302; Lange, Umweltverwaltungsrecht, Section I sidenote 52; Lange, EIA Act (UVPG), § 12 sidenote 11; Sellner, ,Der integrative Ansatz im Bundes-Immissionsschutzgesetz', in: Dolde (ed.), Umweltrecht im Wandel, 2001, 401, 405 f.; Soell/Dirnberger, Neue Zeitschrift für Verwaltungsrecht 1990, 705, 708 f.; Steinberg, Deutsches Verwaltungsblatt 1990, 1369, 1371, (a different view ibid., Deutsches Verwaltungsblatt 1988, 995 [999]); Wahl, Deutsches Verwaltungsblatt 1988, 86, 88. In contrast, a purely procedural law approach of the environmental impact assessment is represented in the Compilation of the Decisions of the German Federal Administrative Court (Bundesverwaltungsgericht) 100, 238, 243; Appold, in: Hoppe (ed.), UVPG, 2nd ed. (2002), § 1 sidenote 25; Di Fabio, Neue Zeitschrift für Verwaltungsrecht 1998, 329, 333; Dürr, in:

Knack (ed.), Verwaltungsverfahrensgesetz, before $\S 63$ sidenote legal authorisation provisions within their wording, in order to allow for the required cross-media evaluation of environmental impact. As the obligation to comply with applicable laws makes the specific wording of the law constitute a limit to any interpretation, the implementation of the integrative approach required by the EIA could only take place via the facts of the case that are open to interpretation. The authorisation requirements ${ }^{104}$ as well as the discretion provisions ${ }^{105}$ described as indefinite legal terms can be considered as components of the norm that are suitable for integration. However, the principle of definiteness and predictability of legal norms ${ }^{106}$ stipulated in Article 20(3) of the German Basic Law (Grundgesetz) is contrary to this „EIAconsistent "107 interpretation that is „in line with the precautionary principle". ${ }^{108}$ Due to the unchanged substantial facts of the case for the authorisation there is also no legislative intention aiming at this. ${ }^{109}$ The opposite only applies when the specific individual law contains a substantial integration approach (see $\mathbb{\int} 6$ Bundesimmissionsschutzgesetz - Federal Immission Control Act, $\int 7(2)$ No. 6 Atomgesetz - Atomic Energy Act). However, it is still questionable whether this type of extension beyond the addition of the media-specific control procedures leads to the consideration

20; Hoppe/Deutsch, ,Umweltschutz und Raumordnung sowie Bodennutzung', in: Rengeling (ed.), EUDUR II/2, § 87 sidenote 128; Schink (supra note 22), 837, 842; Schmidt/Preuß, Deutsches Verwaltungsblatt. 1995, 485, 488 ff.; Weber/Hellmann, Neue Juristische Wochenzeitschrift 1990, 1625, 1628, 1630 f.; Hoppe/Beckmann/Kauch, Umweltrecht, § 8 sidenote 93.

104 Wahl, Deutsches Verwaltungsblatt 1988, 86, 88 f.

105 Beckmann, supra note 18, § 12 sidenote $64 \mathrm{ff}$. (sidenote $72 \mathrm{ff}$., in particular sidenote 76 on the one hand; sidenote $112 \mathrm{ff}$., in particular sidenote 129 on the other hand); Erbguth/Schink, supra note $18, \S 12$ sidenote $35 \mathrm{ff}$. on the one hand; sidenote $52 \mathrm{ff}$. on the other hand.

106 Beckmann, supra note 18, § 12 sidenote 76; Schink/Erbguth, Deutsches Verwaltungsblatt 1991, 413, 419.

107 See Beckmann, supra note 18, § 12 sidenote 67 (with a deprecatory result; see ibid., in another location $\S 12$ sidenote 76 ).

108 Peters, Natur und Recht 1990, 103, 105; on a similar note ibid., Umwelt- und Planungsrecht 1994, 281, 283; see Bundestagsdrucksache (German Parliament Printed Document) 11/3919, 27 and Bundestagsdrucksache (German Parliament Printed Document) 11/5532, 31.

109 Beckmann, supra note 18), UVPG, § 12 sidenote 76; SchmidtPreuß, ,Die Umweltverträglichkeitsprüfung im deutschen Recht und in der Rechtspraxis', in: Vollkommer (ed.), Die Erhaltung der Umwelt als Herausforderung und Chance, 39, 51. See also Bundestagsdrucksache (German Parliament Printed Document) 11/3919, 27 on the one hand, Bundestagsdrucksache (German Parliament Printed Document) 11/5532, 31 on the other hand. 
of the interactions between the different environmental media. ${ }^{110}$ The restriction of the exercise of discretion to the generally media-oriented purpose of the law stipulated in $\mathbb{\int} 40$ of the Administrative Procedure Act impedes the incorporation of the notion of integration. ${ }^{111}$ In addition, a directive-oriented interpretation of the law that is done independently of the wording would contradict the fundamental idea behind Article 249(3) of the EC Treaty and violate the powers of the national legislators, to whom the ultimate decision on how implementation takes place is reserved. ${ }^{112}$ Furthermore, the boundaries set for the direct impact of directives ${ }^{113}$ would almost be arbitrarily undermined in this way. ${ }^{114}$ The environmental impact assessment thus does not possess an integrative capacity, unless the respective specific law contains a substantive material integration approach, which is also open for taking into account any eco-systemic interactions. ${ }^{115}$

In this respect, only integrative provisions can provide the basis for the incorporation of the EIA. One such provision is $\mathbb{\int} 6(1)$ of the Federal Immission Control Act (Bundesimmissionsschutzgesetz), as long as the general integration clause of $\int 1(2)$ is understood as an 'interpretational point of reference', which facilitates the linkage of the basic obligations mentioned in $\mathbb{5} 5(1)$ of the Federal Immission Control Act. ${ }^{116}$ Otherwise, the eco-systemic approach required to implement the EIADirective is lacking. What also has to be taken into

110 Critique in this respect Erbguth, Die Öffentliche Verwaltung 1988, 481, 483; ibid., Natur und Recht 1997, 261, 265; in agreement Büllesbach, supra note 27, $329 \mathrm{f}$.

111 See Steinberg, Deutsches Verwaltungsblatt 1988, 995, 999. According to another view, the coming into force of the EIA created new directives for discretion; see Soell/Dirnberger, Neue Zeitschrift für Verwaltungsrecht 1990, 705, 708.

112 Furthermore, according to the prevailing opinion the interpretation consistent with the directive - just like any form of interpretation - finds its boundary in the wording of the respective norm. See Müller/Christensen, Juristische Methodik, sidenote $428 \mathrm{e}$.

113 See only Herdegen, Europarecht, sidenote 183.

114 See Streinz, Europarecht, sidenote 405.

115 Erbguth/Schink, sopra note 18, § 12 sidenote 102 .

116 Kugelmann, Deutsches Verwaltungsblatt. 2002, 1238, 1244 The addition to $\S 48(1)$ of the Federal Immission Control Act supports this view to the extent that, when specifying the requirements, shifting effects between the elements of the environment are to be taken into consideration and a high level of protection is to be guaranteed on the whole.

117 This results on the one hand from the temporal restrictions on the water law authorisation, which are not known to the consideration in this context is the restriction of the concentration effects by $\mathbb{1} 13$ 2nd Clause of the Federal Immission Control Act. The water law licence simultaneously required here is particularly and in different ways incompatible with the authorisation under immission protection law. ${ }^{117}$ Moreover, the immission law authorisation, that is designed as a control licence, does not allow for the weighing of different options necessary for a comprehensive assessment ${ }^{118}$ nor does it offer a sufficient guarantee for an evaluation of alternatives, because the role of the authorising agency is restricted to the assessment whether the application for authorisation complies with the authorisation requirements of the specific law. ${ }^{119}$ In contrast, the location evaluation of $\mathbb{\int} 7(2)$ No. 6 of the Atomic Energy Act, ${ }^{120}$ the wording of which was adjusted by Article 3 sec. 1a of the Act to implement the EIA-Directive, constitutes a potential starting point for the incorporation of the EIA, because the facts surrounding the licence are explicitly open to the consideration of alternative locations. ${ }^{121}$

\section{a. England}

\section{Formal transposition}

The EIA Directive is formally transposed into national law by means of the Town and Country Planning Regulations $1988^{122}$ and $1999^{123}$. Along with that, it is only since the beginning of our period of analysis that English law has demonstrated a

immissions control law, and on the other hand from the clash between the exceptional authorisation (Ausnahmebewilligung) and the control licence or Kontrollerlaubnis which is bound to the Basic Law. See Zöttl, Journal of Environmental Law 2000, 281, 283.

118 Koch, in: Koch (ed.), Umweltrecht, 2002, § 4 sidenote 148.

119 Erbguth/Schink, supra note 18, § 12 sidenote 40.

120 See Peters, Umweltverwaltungsrecht, Section I sidenote 52; Steinberg, Deutsches Verwaltungsblatt 1988, 995, 999; ibid., Deutsches Verwaltungsblatt 1990, 1369, 1370; Weber/Hellmann, Neue Juristische Wochenzeitschrift 1990, 1625, 1631. In Article 3 sec. $1 \mathrm{a}$ of the Act on the Implementation of the EIA Directive, this regulation was worded as follows: 'überwiegende öffentliche Interessen, insbesondere im Hinblick auf die Umweltauswirkungen, der Wahl des Standorts entgegenstehen' (primarily public interests, in particular with regard to the environmental impact, stand in the way of the selection of the location) instead of previously: 'im Hinblick auf die Reinhaltung des Wassers, der Luft und des Bodens' (as regards keeping the water, air and soil clean) (cursive by the author).

121 Erbguth/Schink, supra note 18, § 12 sidenote 41 .

122 SI 1988 No 1199. See sec. 71A-(1) Town and Country Planning Act 1990.

123 SI 1999 No 293. 
greater degree of standardisation of environmental law previously designed as case law. Examples of particularly decisive legislative acts are the introduction of the Environmental Protection Act 1990 (EPA) as well as the Environment Act 1995 (EA), which follow an integrative approach and provided the impetus for the enactment of the IPPC Directive. $^{124,125}$ The most important components of the integrative approach are now guaranteed by the introduction of the Pollution Prevention and Control Act 1999 (PPCA). ${ }^{126}$ With regard to this, there is evidently an increased standardisation of preventive components in the form of authorisation requirements. ${ }^{127}$

\section{Substantial structure}

\section{Procedural component}

The procedural regulations of the EIA Directive are now standardised in the Town and Country Planning Regulations of 1999. Furthermore, English law regulations are increasingly characterised by demands for public participation. ${ }^{128}$ In this respect, superior judicial decisions also emphasize that the procedure is not only supposed to ensure that the decision-making agency is provided with complete information, but that the procedure must also comply with democratic requirements, according to which the public must be given the opportunity to

124 See the verification in footnote 16 .

125 Masing, Deutsches Verwaltungsblatt 1998, 549, 552; Zöttl, Journal of Environmental Law 2000, 281, 281.

126 Zöttl, Journal of Environmental Law 2000, 281, 281.

127 E.g. by means of the Water Act 1989, the EPA 1990 as well as the PPCA 1999.

128 See e.g. sec. 13 TCPA 1990

129 Case Law Analysis, House of Lords, Berkeley v. Secretary of State for the Environment and Others, Journal of Environmental Law 2001, 89, 96.

130 Elvin/Robinson, Journal of Planning and Environmental Law 2000, 876, 886 .

131 See the verification in Case Law Analysis, House of Lords, Berkeley v. Secretary of State for the Environment and Others, Journal of Environmental Law 2001, 89, 99 footnote 2.

132 Case Law Analysis, House of Lords, Berkeley v. Secretary of State for the Environment and Others, Journal of Environmenta Law 2001, 89, 96 f.. See Ladeur/Prelle, Journal of Environmental Law 2001, 185, 193.

133 See Thornton/Beckwith, Environmental Law, 2nd ed. (2004), sidenote 13-042 ff.

134 Kloepfer/Mast, Umweltrecht des Auslandes, 1994, 119.

135 See Thornton/Beckwith, supra note 133, sidenote 13-004. offer its opinion on the matter, regardless of the fact that it is potentially incorrect or misguided. ${ }^{129}$

In any case, what is decisive for the procedure is the significance of existing procedural errors. English law does indeed guarantee the right to a fair procedure. However, in individual cases errors may remain irrelevant, as long as the desired degree of fairness has been achieved in the outcome. Furthermore, in accordance with the Town and Country Planning Act of 1990 the courts are granted the discretion to uphold a decision, even when it is flawed. ${ }^{130}$ Against this background, the improper or neglected participation of the public in the planning of a project subject to an EIA was regarded as insignificant in a series of earlier decisions, as long as no influence on the result of the decision could be discerned. ${ }^{131}$ With respect to the democratic notion of the EIA, a more recent superior judicial decision now deviates from this concept by standardising a judicial obligation to revoke a planning decision („planning permission“) exclusively by invoking a procedural error of this nature. Hence, despite the complete information provided to the agency in charge of the decision (without public participation) and the lack of influence on the decision outcome, the irrelevance of such an error is denied with reference to Article 10 of the EC-Treaty. ${ }^{132}$ Thus the court attaches decisive importance to the participation of the public in accordance with the EIA Directive.

\section{Substantial component}

In England, the integration of the EIA primarily takes place by means of planning procedures according to the Town and Country Planning Act. ${ }^{133}$ Although there is no sectoral or elementspecific planning process in English law that is comparable to the legal situation in Germany, the "land-use-planning“" procedure is of great relevance to the reduction of the land use and thus to the protection of the environment. ${ }^{134}$ In individual cases, these planning decisions can also be project-related and can above all be distinguished from the subsequent authorisation procedures by the constant monitoring function and the orientation of the latter towards individual companies or persons. ${ }^{135}$ From a substantial perspective, the EIA is observed within the individual planning procedures, the content and design of which are traditionally open to a broad space for discretion that is hardly regulated by any content-related guidelines. Both the integra- 
tive decisions as well as the strong orientation towards concerns of environmental law ${ }^{136}$ facilitate the implementation of the EIA.

Furthermore, facility authorisation procedures also offer a sufficient basis for a comprehensive incorporation of environmental concerns. Along these lines, the Pollution Prevention and Control Act 1999 (PPCA) is of primary importance here. The integrated pollution control stipulated here (see sec. 1-[2] PPCA) provides for a far-reaching authorisation procedure that is extremely flexible in terms of content. ${ }^{137}$ For example, the conditions which the agency deems appropriate are to be stipulated in the authorisation in accordance with various openly formulated guidelines using subjective language. ${ }^{138}$ The authorisation requirements are essentially specified on the basis of an individual case-based assessment, bearing in mind the concept of the best practicable environmental option (BPEO) stipulated in sec. 7-(7) of the EPA. Ideally, the environmental effects of the project should be assessed during the authorisation procedure by taking into account their interactions in order to reduce these effects to the greatest extent possible in terms of ecological and economic aspects. It thus seeks to ensure an optimised balance between heterogeneous ecological concerns. ${ }^{139}$ As a matter of fact, these authorisation procedures are also subject to comprehensive assessment in accordance with the EIA-Directive, in which various options are weighed.

\section{Administrative implementation}

\section{a. Germany}

Since the EIA was integrated into existing structures and procedures for authorising facilities, a highly fragmented administrative practice that is differentiated for each element of the environment remains in place in Germany, regardless of the directive's requirements in view of an integrated concept. ${ }^{140}$ Even though increasing coordination between the different agencies involved within the framework of the EIA can be observed, ${ }^{141}$ there still is the problem that there is no homogenous procedural structure uniting different powers and authorities for assessment and evaluation of environmental effects across all elements of the environment. ${ }^{142}$ The agency responsible for the authorisation procedure evaluates the environmental impact declaration of the project manager with regard to the authorisation to be issued. Here, the evaluation is made on the basis of the respective authorisation requirements in accordance with the pertinent specific legal regulations. In this context, the responsible authority consults the special agencies involved, which often exercise considerable influence on the procedure. This procedure may indeed enable the fusion of different specific legal evaluations. However, an assessment across all elements of the environment, as explicitly required by the EIA Directive, only plays a subordinate role. ${ }^{143}$

Administrative modifications that could even partially help meet these demands can hardly be expected at the moment. The above-mentioned draft of an Environmental Act also primarily focuses on the integration of different environmental law procedures without affecting existing administrative structures for the most part.

\section{b. England}

In England as well, the implementation of the EIA Directive primarily took place by integrating the European guidelines into existing legal and administrative structures of planning law. As illustrated above, the local authorities responsible here have a great scope of discretion, something which essentially encourages assessments across all elements of the environment in a better way than is the case in Germany with its reference back to individual regulations in special law areas. As a consequence, in

136 See Thornton/Beckwith, supra note 133, sidenote 13-026.

137 Masing, Deutsches Verwaltungsblatt 1998, 549, 552.

138 According to sec. 7-(1) (a-c) of the EPA this concerns such conditions 'as the enforcing authority considers appropriate, ... for achieving the objectives specified ... below', 'as are specified in directives given by the Secretary of State...' and 'as appear to the enforcing authority to be appropriate'.

139 Volkmann, Verwaltungsarchiv 89 (1998), 363, 373.

140 Lambrechts, Environmental Impact Assessments, in: Winter (ed.) European Environmental Law. A Comparative Perspective, 1996, 63, 77; Schwarze, Country Report on Germany, in: Schwarze (ed.), Administrative Law under European Influence, 1996, 123, 169.

141 Knill, supra note 1, 147

142 Commission of the European Communities, Report from the Commission of the Implementation of Directive 85/337/EEC on the Assessment of the Effects of Certain Public and Private Projects on the Environment, 1993, 122.

143 Heinelt et al., supra note 33, 112; Zöttl, Journal of Environmental Law 2000, 197. 
England there was lower need for administrative adaptation in order to ensure an effective implementation of the EIA Directive. ${ }^{144}$

The only thing that was necessary was improving coordination in cases, where planning and authorisation procedures were conducted at different administrative levels. This applies to the great majority of environmentally-relevant projects. While local authorities are responsible for the implementation of the EIA, the central Environment Agency is in charge of issuing authorisations for facilities. Up to now, there has not been any effective coordination between both levels during the EIA evaluation. The planning authorities thus frequently criticise the lack of information with regard to the technical characteristics of the relevant facilities, which would have been required for an effective assessment across all elements of the environment. These deficits and the poor adaptation of administrative structures are not least due to the lacking hierarchical relationships between the central and local levels, something which is characteristic of the English administrative system in general. ${ }^{145}$

Despite this shortcoming in terms of coordination between local planning agencies and the central authorizing authorities, one should point out here that comprehensive integration of the different element-specific authorisation procedures at central level has taken place in the course of the vast environmental law reforms in England since 1990. Instead of separate controls depending on the element of the environment concerned, the Environmental Protection Act from 1990 stipulates that all technically complex projects must be assessed by an agency based on an integrated ap-

\footnotetext{
144 Haigh, supra note $35,11.2-18$; Knill, supra note 1,173 ; Heinelt et al., supra note 33, $243 \mathrm{ff}$.

145 Knill, supra note 1, 173.

146 Barth/Demmke/Ludwig, Natur und Recht 2001, 133, 135 Masing, Deutsches Verwaltungsblatt 1998, 549, 552 f.; see also Héritier/Knill/Mingers, supra note 146, 220. The English reforms had a decisive impact on the IPPC-Directive passed at the European level in 1996.

147 However, this development can not only be traced back to the influence of the European EIA Directive. Instead, these adjustments in English environmental law are to a great extent due to the effects of several other environmental measures by the EU in the area of air and water pollution control, which provided for the introduction of binding procedural and authorisation standards, see Knill, supra note 1 .

148 On the proceduralisation of environmental law, see Steinberg, supra note $57,427 \mathrm{ff}$.
}

proach (integrated pollution control). This aims at ensuring an optimum allocation of the burden between different elements of the environment (BPEO-Principle). ${ }^{146}$

\section{Overall assessment}

\section{a. Convergence with regard to formal elements}

As for formal elements, we can observe a convergence of national regulations in various areas of the developments described. Firstly, English law is marked by a more frequent introduction of preventive monitoring mechanisms, ${ }^{147}$ meaning that a certain degree of convergence when compared to the legal situation in Germany has taken place. Secondly, with respect to carrying out the procedures both legal systems are converging during the implementation of the European law provisions, because the procedural requirements are being increased in German law. ${ }^{148}$

In part, we can also detect a concurrent development inasmuch as the significance of the procedure has been strenghened in both legal systems. This becomes apparent, on the one hand, when considering the greater emphasis placed on the (democratically enriched) notion of participation. On the other hand, the greater significance of the procedure is evident in terms of the attention given to relevant procedural errors. Under the pressure exercised by European law provisions, German environmental law regulations have deviated from their originally substantial structure, because the disregard for the procedural element of environmental law expressed by $\mathbb{4} 46$ of the Administrative Procedure Act (Verwaltungsverfahrensgesetz) is amended by $\mathbb{3}$ of the draft of the environmental right to appeal Act and substituted emphasizing the procedural element. Similar developments can also be observed in England, where, according to the case law modification from 6 July 2000 after the decision Berkeley $\mathrm{v}$ Secretary of State for the Environment and Others, the court's discretion in the case of apparent EIA-related procedural errors is consolidated into a revocation obligation.

\section{b. Convergence with respect to substantial elements}

With regard to the substantial approach rooted in the directive, the national regulatory systems have 
an inhibiting effect during the implementation of the European guidelines. Here, we have observed that national bodies retreat to the concrete wording of the directives during implementation, as long as the national regulatory system does not provide for the instruments required for implementation in compliance with the given objectives. Thus existing differences between the different national regulatory systems often remain intact. This is illustrated particularly well by the implementation of the EIA in German law. Satisfactory implementation has only taken place with regard to the final procedures. With this in mind, we only detect convergence of legal structures to the extent that the national regulations are linked to a similar system. When considering that an assessment across all elements of the environment was also introduced for facility authorisation procedures in England in the course of the comprehensive legislative activities in environmental law that thas taken place since the beginning of the 1990s, we can even observe a partial divergence of the substantial law developments in both countries over time, in particular with regard to the German situation.

\section{c. Convergence with regard to administrative structures}

Neither in Germany nor in England did the implementation of the EIA Directive lead to an approximation of existing administrative structures. Instead, the highly different national arrangements persist, which can in part be traced back to the extensive differences in the national constitutional and administrative traditions. In both countries, the persistence of these structures lead to the partially insufficient implementation of the EIA Directive. In Germany, this has to do in particular with an administrative organisation geared towards individual elements of the environment. In England, the traditional absence of distinctive and effective coordination mechanisms between central authorising authorities and local planning agencies pose a general problem when it comes to effective implementation.

\section{Results and conclusions}

On the whole, we may conclude that in Germany and England, the implementation of the EIA direc- tives was by no means accompanied by any general approximation of the respective legal and administrative structures over time. Instead, we can observe a complex pattern consisting of both convergent and divergent developments as well as parallel changes (and thus also the persistence of existing differences). Another factor is that convergent and divergent trends are subject to certain fluctuations over time.

Thus, in conclusion, the question arises how we should interpret and explain the empirical findings presented above. In this respect, several factors should be stressed. Firstly, we should point out the potential cost of institutional and legal adjustments. The greater the effort involved in harmonizing existing national arrangements with the guidelines stipulated by the European directives, the lower the overall probability that such adjustments actually take place. This is demonstrated very clearly in the example of the administrative structures. In both countries, any such modifications (cross-element administrative structures in Germany, coordination between central and local level in England) would have required the introduction of reforms, which would have implied the necessity of moving away from highly institutionalised patterns of national legal and administrative traditions. ${ }^{149}$ Changes of this nature would have in turn penetrated deeply into the institutional system as a whole and would have been associated with great costs and effort. The same applies to the substantial design of the EIA, which was integrated into existing planning and authorisation structures in both countries. Conversely, the convergence of procedures - even though this was only hesitant - took place with lower institutional costs. In Germany, this was feasible because related innovations remained restricted to the EIA and thus did not result in any further harmonisation in the general administrative procedure. In England, the cost of institutional adjustment was reduced due to the partial simultaneity of the European procedural guidelines and independent, partially nationally inspired reforms in environmental law. ${ }^{150}$

Secondly, different developments in terms of domestic change and reforms can be traced back to

149 See Knill, supra note 1, $20 \mathrm{ff}$.

150 See Héritier/Knill/Mingers, supra note 146, 208 ff. 
potentially varying means of influence and political mobilisation of social actors. ${ }^{151}$ In particular in cases where European law contains precise regulatory guidelines, such actors have an instrument to point to national implementation problems and, if necessary, enforce them by law. These possibilities are clearly granted to a greater extent during the EIA procedure and in particular in terms of public participation than is the case for the design of the substantial legal consequences and the administrative executive structures. In the latter cases, the guidelines of the European directives still remain very unspecific. This general openness makes it easier for political and administrative actors to legitimise the persistence of existing arrangements regardless of their possible shortcomings. In this context, one also has to bear in mind that procedural requirements can be specified in much more detailed way than substantial requirements, which must grant national legislators great freedom of implementation as these requirements are deeply rooted in the existing legal systems.

Thirdly, one must take into account that changes to national environmental policy arrangements do not necessarily have to be reactions to European guidelines. For example, it is certainly plausible that divergent or convergent developments in the environmental policies of the Member States are a result of genuinely national reform developments which, to a large extent, take place independently of developments at the European level. As for the cases addressed here, this is illustrated particularly well by the introduction of an integrated authorisation procedure in Great Britain, which encompasses all elements of the environment. This development was primarily based on national decisions to introduce reforms and was not triggered by European measures. Instead, it was the English

\footnotetext{
151 See Börzel, Improving Compliance Through Domestic Mobilisation? New Instruments and the Effectiveness of Implementation in Spain, in: Knill/Lenschow (eds.), Implementing EU Environmental Policy: New Directions and Old Problems, 222.

152 Ladeur, supra note $58,1,9$.
}

BPEO principle that inspired the development of a corresponding European Directive.

Fourthly, we must point out that the extent of convergence of national legal and administrative structures is not exclusively influenced by national developments and factors. Instead, an analysis over a longer period of time shows that directives, once passed at the European level, can be subject to a process of sequential revision and further development. In view of any implementation deficits concerning the initial directive, the EU Commission, in particular, initiates measures to 'update' and 'finetune' the implementation process, in order to correct these shortcomings by means of more precise regulatory guidelines. As for the EIA, this has taken place within the framework of several measures (EIA-Amendment Directive, SEA-Directive, Public Participation Directive). However, the directives concentrate in particular on procedural aspects rather than on administrative structures and substantial legal consequences of the EIA. Against this background, it is not surprising that the empirically observable convergences are much more pronounced with regard to the procedure than in the other areas considered here. The concentration on procedural regulations described above is due to the fact that from the EU's point of view, Europeanisation effects can be achieved in a particularly efficient way by harmonizing procedural structures, because on the one hand, Member States cannot autonomously shape their implementation process and are thus subject to rational control and because on the other hand, this creates the greatest possible level of transparency in national decisionmaking structures. ${ }^{152}$

Thus, on the whole, it appears that the question whether and to what extent the Europeanisation of national legal and administrative structures leads to convergent developments depends on several factors. The effects of these factors can differ from country to country and depending on the different aspects considered (procedures, substantial legal consequences, administrative structures). The result is that convergent developments can by no means be expected to be a general trend, but rather constitute a merely partial phenomenon. 